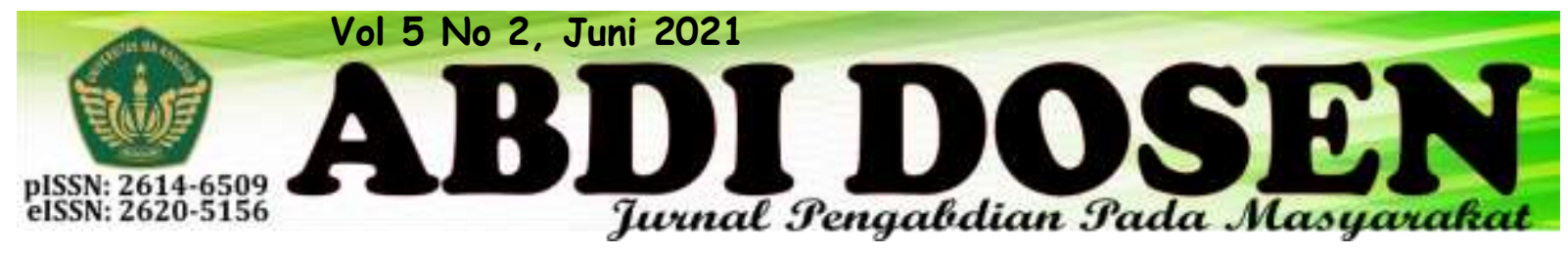

\title{
STRENGTHENING CHARACTER EDUCATION THROUGH SCHOOL CULTURE AT SMK SWASTA TELADAN TANAH JAWA
}

\author{
Herman $^{1}$, Dumaris E. Silalahi ${ }^{2}$, Partohap Saut Raja Sihombing ${ }^{3}$, Bloner Sinurat ${ }^{4}$, Yanti
} Kristina Sinaga ${ }^{5}$, Muktar B. Panjaitan ${ }^{6}$, Christian Neni Purba ${ }^{7}$, Bertaria Sohnata Hutauruk ${ }^{8}$, David Togi Hutahaean ${ }^{9}$, Tiarma Intan Marpaung ${ }^{10}$, Marnala Pangaribuan ${ }^{11}$, Lydia Purba ${ }^{12}$, Bangun Munte ${ }^{13}$, Tumpal Manahara Siahaan ${ }^{14}$

herman@uhn.ac.id ${ }^{1}$, dumaris.silalahi@uhn.ac.id ${ }^{2}$, partohap.sihombing@uhn.ac.id ${ }^{3}$, bloner.sinurat@uhn.ac.id ${ }^{4}$,

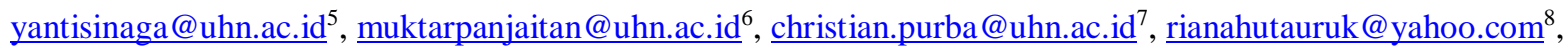

david.hutahaean@uhn.ac.id ${ }^{9}$, tiarma.marpaung@uhn.ac.id ${ }^{10}$, marnala.pangaribuan@uhn.ac.id ${ }^{11}$,

lydiapurba@uhn.ac.id ${ }^{12}$, bangunmunthe@uhn.ac.id ${ }^{13}$, tumpalsiahaan@uhn.ac.id ${ }^{14}$

Universitas HKBP Nommensen Medan, Indonesia

Jalan Sutomo No. 4, Medan

\begin{abstract}
Schools must recognize that school culture has an effect on the development of character in students. With the prevalence of numerous character flaws among students, it is expected that through school culture, students will be able to form their character through a school-based habit. Teachers at SMK Swasta Teladan in Tanah Jawa, Simalungun Regency, were the recipients of this community service. Thirty-three teachers were among those who took part in the socialization. This was a qualitative research project with a descriptive approach. The approaches used in this case are lectures and group discussions, with information being given first, followed by a question and answer session about the material. After having all methods provided, the results of the socialization through the school culture implementation possibly to be implemented to support the character education were: 1) cultivating religious tolerance values, 2) The implementation of school ceremonies, 3) implementation of working groups (PokJa) in schools, 4) The use of student-centered learning (student-oriented learning) during the learning process, 5) Using scouts in schools for students' training to be more independent, and the last was prizes should be granted to students including all areas events, not only for academic areas. Last but not least, the role of school culture really can strengthen and support the character education for the students.
\end{abstract}

\section{Keywords: character education, school culture, students' character, socialization}

\section{INTRODUCTION}

The aim of national education, according to Law No. 20 of 2003, is to develop students' capacity to become human beings who believe and fear God Almighty, have noble character, are safe, informed, competent, imaginative, autonomous, and democratic citizens of the state. to be responsible. It is also hoped that education would lead to a better quality of life. It is also hoped that life will improve as a result of schooling. As a consequence, schooling is a mechanism that any human being needs (Trianto, 2014).

To face the new age of globalization, 
education plays an important role in a nation's and country's development. In Indonesia, education has changed frequently in order to generate skilled human capital. However, current schooling is still missing due to the nation's children's current mindset. As a result, in 2017, the government initiated a character education initiative, which was also a focus program during President Joko Widodo's and Vice President Jusuf Kalla's administration from 2015 to 2019. The program was named Nawacita. One of the nine essence of the Nawacita program is the Strengthening of Character Education (PKK) which contains "Revolutionizing the character of the nation through the policy of restructuring the national education curriculum by prioritizing aspects of civic education, which proportionally place aspects of education, such as teaching the history of nation formation, the values of patriotism and love for the country, the spirit of defending the country and manners in the Indonesian education curriculum.

One of the reason why government launched the character education is because of the character. Character refers to a person's personality traits that are innate or acquired. Character flaws include the inability to work in isolation, preferring instead to function in a social setting. The Human Resources (HR) aspect cannot be overlooked, as shown by the numerous awards won by Indonesian children in international competitions and competitions, both in the fields of education and sports. The goals of character education can only be achieved through the younger generations. One of the most important places for forming a person's character is school. Schools have had a main aim in the field of education for a long time, which is to form intelligent human beings of strong character or character. To achieve these objectives, schools must take on a major role in character education for all students (Supraptiningrum dan Agustini, 2015:2020).

Aside from this remarkable accomplishment, many generations of this nation's character have been weakened, resulting in negative consequences. Let's look at a few cases. To begin with, we often see children who are still under the age of 18 smoking, both at school (often secretly) and outside of school. This is, of course, very disturbing, particularly when it happens in one's own home. Second, brawls between schools involving the nation's future generations, which occur frequently in many Indonesian cities. Indeed, in recent years, the controversy surrounding these brawls has been effectively reduced. Third, student battles, especially those involving bullying of other students. The torture incident at Muhammadiyah Middle School Need Purworejo shocked us just a few days ago by three friends at school. The most heartbreaking part was that he asked for the torture to be videotaped by a friend and made viral. It's as if they're not ashamed of what they're doing and are proud of it. All those who heard and learned about the incident are understandably disappointed. This demonstrates how low our nation's generation's mental and character are.

Based on the problems and phenomena mentioned above, the government launched the character educations. The President then released Presidential Regulation Number 87 of 2017 concerning Strengthening Character Education, demonstrating that PKK is one of the President of the Republic of Indonesia's top priorities. In response to Presidential Regulation No. 87 of 2017, the Minister of Education and Culture 
(Permendikbud) has released Ministerial Regulation No. 20 of 2018, Improving Character Education in Formal Education Units. The introduction of Enhancing Character Education is crucial for developing and educating these children's mental and character growth. The role of a trip-centered education, namely school, family, and community, is suggested in Strengthening Character Education (Herman, 2020)

It is hoped that religious ideals,

\section{METHOD}

Method used in here was decriptive qualitative study. Moelong (2014:6) as cited in Silkyanti (2019:39) explained that qualitative study seeks to achieve a holistic understanding of phenomena encountered by research participants, such as actions, perception, motivation, movements, and others, through explanations in the form of words and language, in a specific social and natural environment. using a variety of natural methods (Herman et al, 2019; Hutabarat et al, 2020). This training as the community service was conducted as the invitation by the headmaster of SMK Swasta Teladan school, Ganti Marulak Hutauruk, M.Pd., in Tanah Jawa. This community service was implemented on 7- nationalism, freedom, and honesty would be encouraged. In this scenario, I'll talk about how schools can help with character education. School Culture is one of the school's contributions in the introduction of Strengthening Character Education. Based on the background above, the researchers are interested to make a Community Service through teachers at SMK Swasta Teladan Tanah Jawa in order to improve the quality of students' character and mental.

8 January 2020 with the permission of Lembaga Penelitian dan Pengabdian Masyarakat (LPPM) or known as Research and Community Services Institutes of Universitas HKBP Nommensen Medan, Indonesia. This events were attended by thirty-three teachers who teach at SMK Swasta Teladan in Tanah Jawa. Lectures and group discussions are the methods used in this case, with information being provided first, followed by a question and answer session about the material. The material were presented through a PowerPoint material for the title about The Role of School Culture on Character Education.

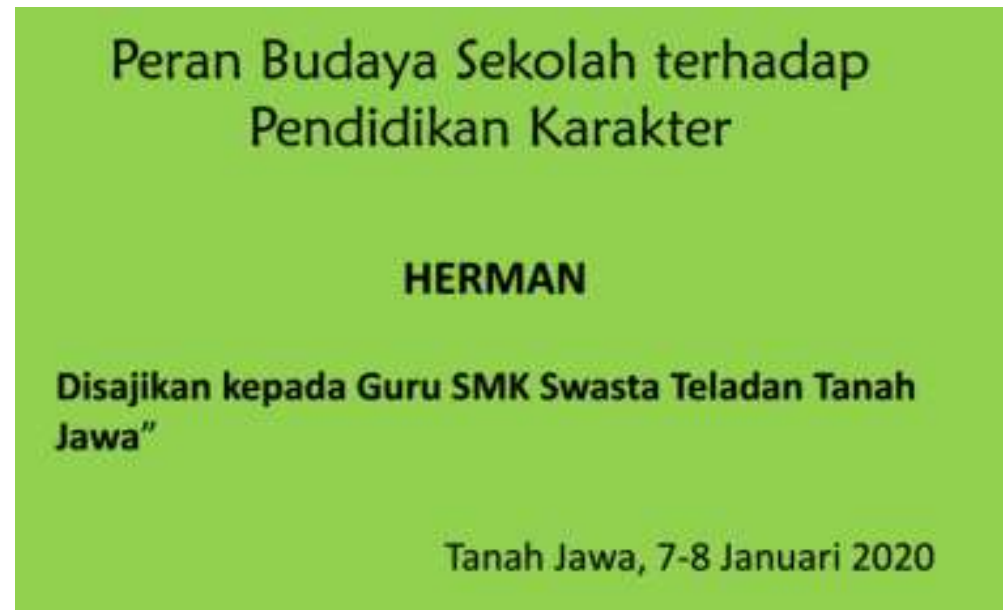

Image 1. Cover of the PowerPoint Presentation for conducting the Community Services 
Setelah mengikuti sesi ini, peserta diharapkan mampu:

- Mengidentifikasi unsur-unsur budaya sekolah yang dapat membina dan mengembangkan karakter siswa

- Memprogram budaya sekolah dalam membina dan mengembangkan karakter siswa

- Mengimplementasikan pembinaan dan pengembangan karakter positif melalui budaya sekolah

Image 2. The Goals for conducting the Community Services

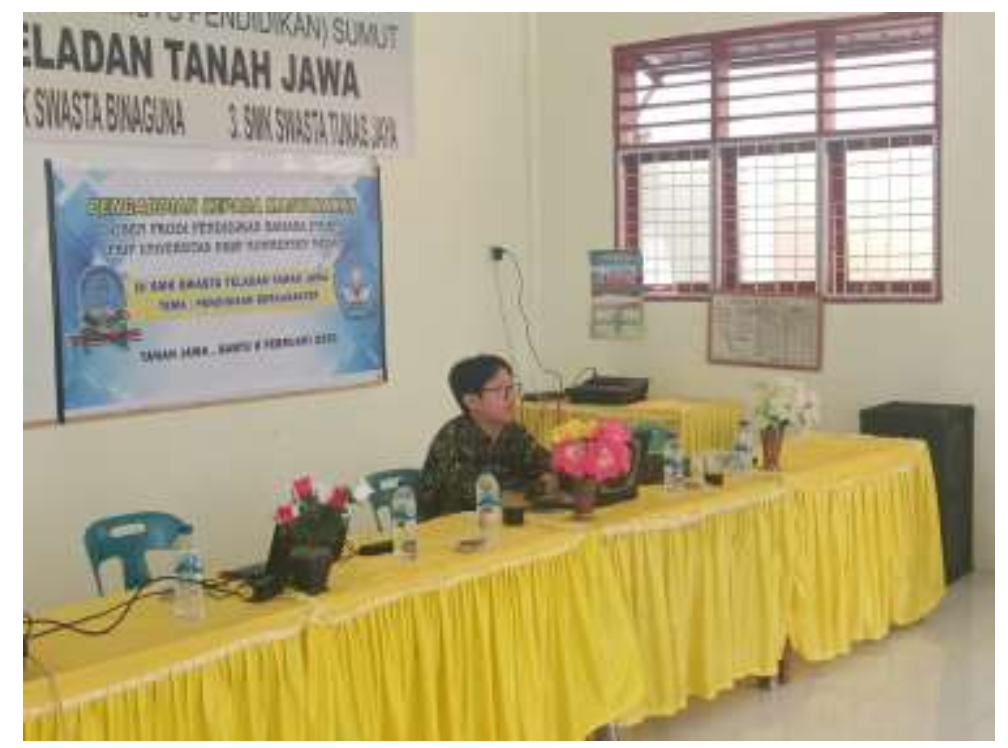

Image 3. Community Service at SMK Swasta Teladan Tanah Jawa

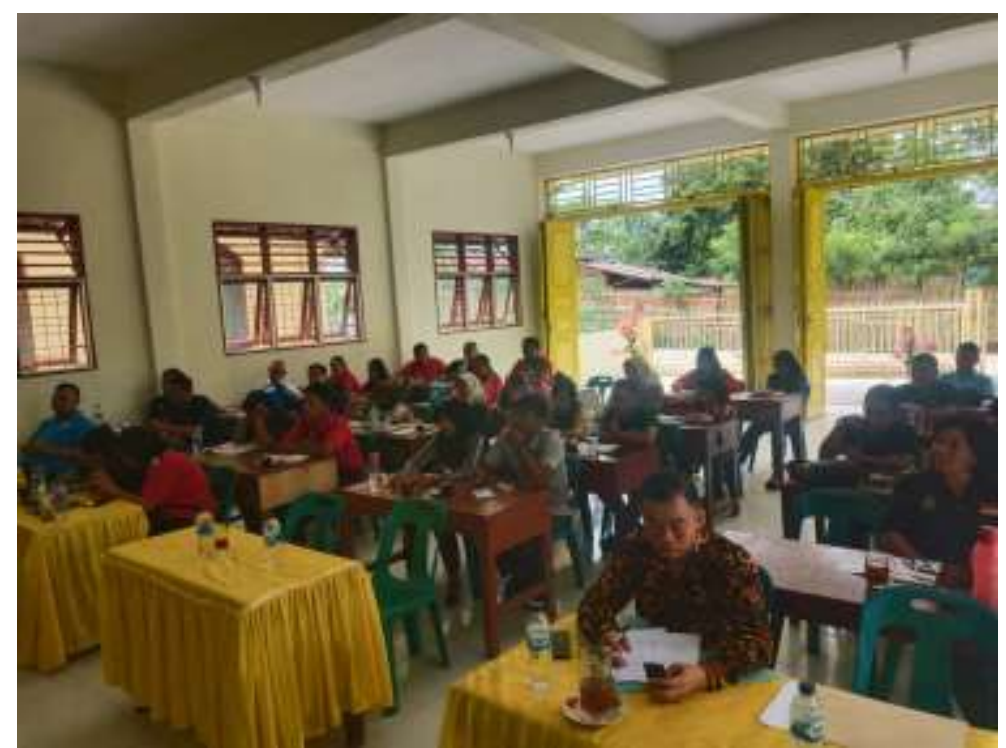

Image 4. Community Service for Teachers at SMK Swasta Teladan Tanah Jawa 
After conducting the workshop as the community service, the researchers got the certificate, letter of acknowledgement and also the attendance list for the report for
LPPM or Research and Community Services Institutes of Universitas HKBP Nommensen Medan, Indonesia. Here are some of the report attached.

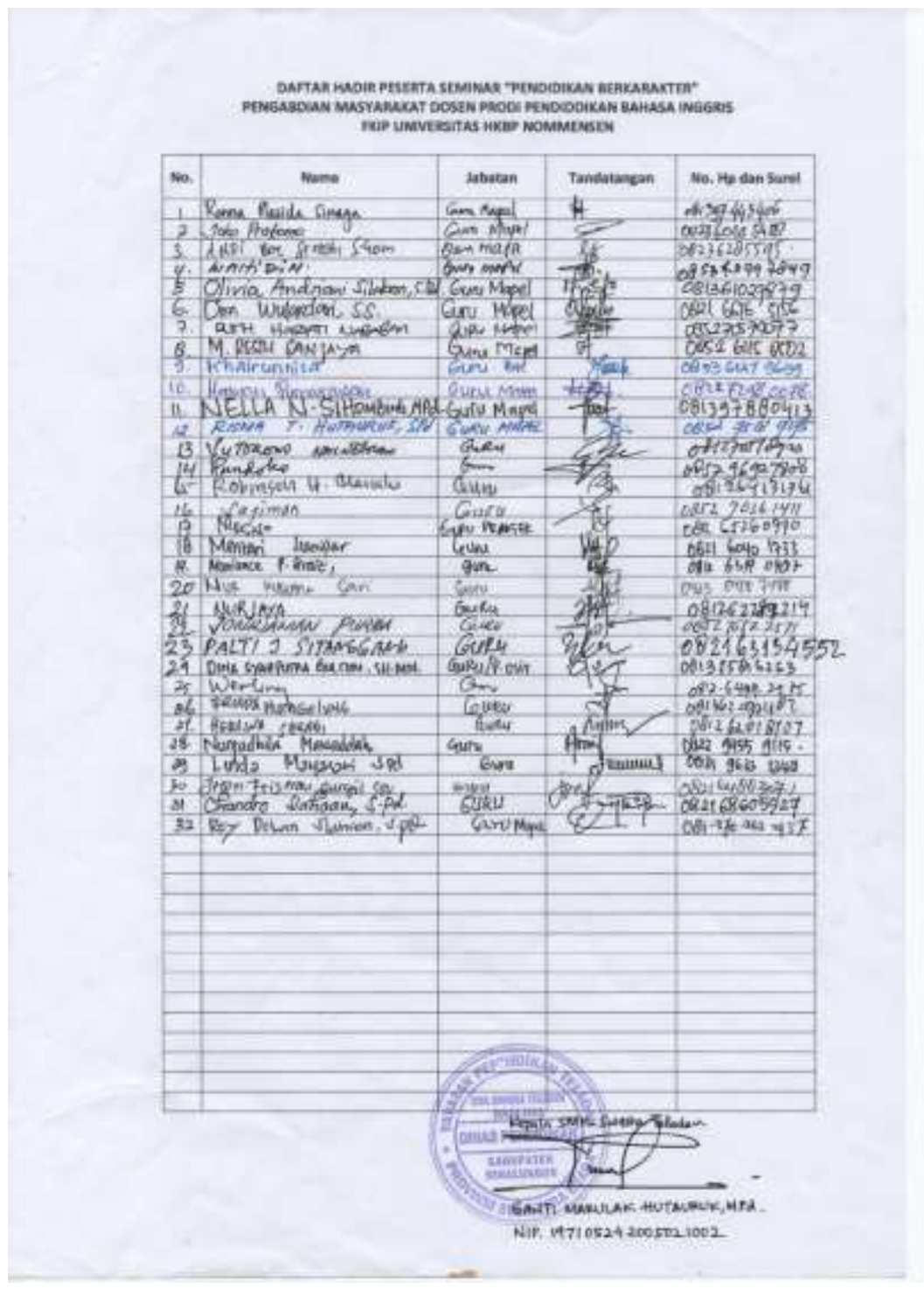

Image 5. Attendance List of the teachers

Image 5 above showed that there are thirty-three teachers as participants in the community service conducted by the lecturers of Universitas HKBP Nommensen
Medan. The teachers were from various subjects of Education in the school such as Religion, Mathematics, English, Mandarin, and so on. 


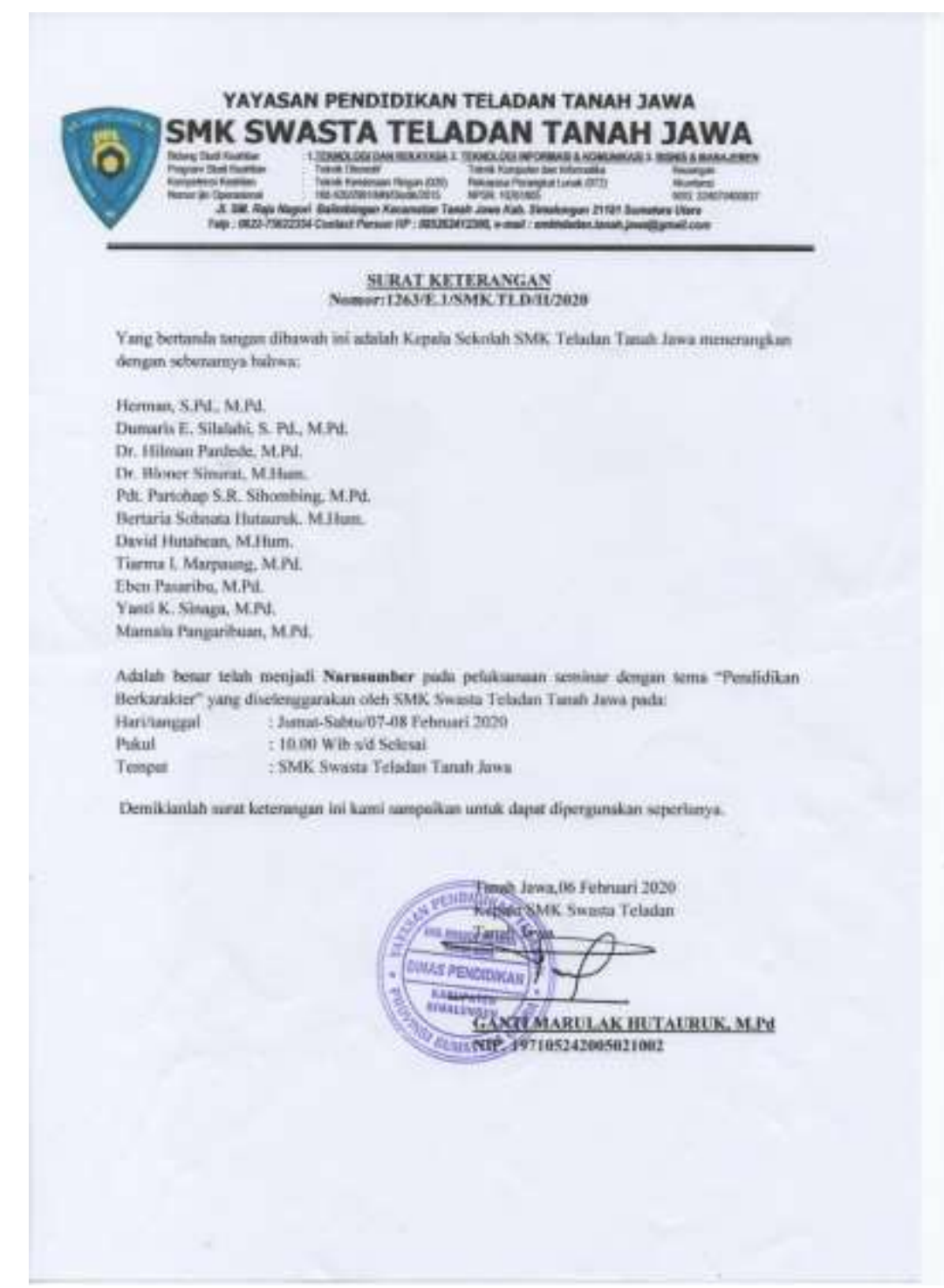

Image 6. Letter of Acknowledgement of conducting the Community Services

\section{RESULTS AND DISCUSSION}

The introduction of socialization and preparation for Teladan Private Vocational School teachers on the role of school culture in the creation of character education received a positive response from the training participants. This socialization and training, according to all participants, was extremely beneficial for improving skills, especially the role of school culture in character education. According to the responses of the training participants, the socialization and training materials were very useful in promoting the implementation of their work as teachers at the Teladan Private Vocational School in Tanah Java, Simalungun Regency in educating school students. They believe that this training material has improved teachers' understanding, especially in terms of integrating different types of school culture toward the mental development and character development of students, which are the primary goals of character education Planning, execution, assessment, and school policy will all contribute to build a character-rich school culture. Some of the outcomes of teachers' positive responses after the sharing in the sessions to the role 
of school culture that can be introduced in schools, including

1. By cultivating religious tolerance values. Non-Muslim children, for example, can assist in the preparation of pre-Friday prayer facilities for their friends who are going to pray during Friday prayers. If there are other religious activities at school, children who do not follow a particular religion are expected to volunteer to assist with whatever is required for the religious event to take place

2. The implementation of school ceremonies. So far, we've learned that flag ceremonies are often held every week, typically on Monday. Children are traditionally qualified to be ceremonial supervisors, conductors, and readers of ceremony program guides. More positive values, such as discipline, freedom, democracy, national spirit, love for the country, and full responsibility, can be gained by involving these children.

3. Working groups (Kelompok Kerja/PokJa) are being implemented in schools. Mutual cooperation character values are also taught in Pokja at school, where students work together to solve common tasks and problems. Pokja can also help people connect and develop friendships

4. The use of student-centered learning (student-oriented learning), which involves asking students active questions and receiving active responses during the learning process. This style of learning model would help students improve more than the conventional teachercentered learning process. Curiosity, a love of reading, creativity, and friendliness or communicativeness are all character traits that can be included

5. Using scouts in schools is a smart idea. Pramuka, as we all know, is an Indonesian non-formal education organization that offers education. Scouting in schools can be used to introduce a range of activities that will inevitably involve almost all school members, especially students. For instance, cleaning the classroom environment as a group activity. Environmental stewardship, duty, and friendliness or communicativeness are examples of character qualities that can be attained. Another example is learning-by-doing things like assisting people crossing the street in front of the school.

6. Finally, prizes should be granted to students who succeed in school in areas such as reading, athletics, social events, painting, and so on. Trophies, coaching fees, scholarships, and other forms of recognition are commonly provided at school. 


\section{CONCLUSION}

As we all know, Pancasila is the source of five key character principles that are priorities for the growth of the PKK movement: religion, nationalism, honesty, freedom, and mutual cooperation. The five principles communicate with one another as they grow, and none of them can stand alone and develop. Depending on the school's position, there are a number of other school cultures that can be introduced. The application of school culture cannot be separated from the participation of teachers

\section{ACKNOWLEDGEMENT}

This socialization or training is fully funded and permitted by Research and Community Services Institutes (Lembaga

\section{THANK YOU NOTE}

The researchers would like to deliver their highest grateful to SMK Swasta Teladan in Tanah Jawa, Simalungun Regency, especially for Mr. Ganti Marulak Hutauruk, M.Pd. that has invited the in schools. The instructor must grow into a figure who can open nature, mind, and soul to enlightenment and cultivate compassion, moral values, exemplary values, behavioral values, and diversity values. As a result, in addition to teaching, teachers play an important role in the welfare of children in schools. Finally, good character-based schooling would create the next generation of superior nations for a nation's and state's development.

Penelitian dan Pengabdian Masyarakat/ LPPM) Universitas HKBP Nommensen, the Year 2020.

researchers to give a socialization and training for all teachers as the community services by the lecturers of Universitas HKBP Nommensen Medan, Indonesia. 


\section{REFERENCES}

Herman, Murni, S. M., Sibarani, B. and Saragih, A. (2019). Structures of Representational Metafunctions of the "Cheng Beng" Ceremony in Pematangsiantar: A Multimodal Analysis. International Journal of Innovation, Creativity and Change., Volume 8, Issue 4, 2019. Retrieved from https://www.ijicc.net/images/v ol8iss4/8403_Herman_2019_E_R.pd $\underline{\mathrm{f}}$

Herman. (2020). Peran Budaya Sekolah Terhadap Pendidikan Berkarakter. Retrieved from: https://www.mistar .id/opini/peran-budaya-sekolahterhadap-pendidikan-berkarakter/

Hutabarat, E., Herman, Silalahi, D.E., and Sihombing, P. S. R. (2020). An Analysis of Ideational Metafunction on News Jakarta Post about Some Good Covid-19 Related News. VELES Voices of English Language Education Society, Vol 4, No 2 (2020), e-ISSN 2579-7484, PP. 142151. Retrieved from http://ejournal.hamzanwadi.ac.id/index.php/ veles/article/view/2526

Peraturan Presiden (PERPRES). (2017).
Peraturan Presiden (PERPRES)

tentang Penguatan Pendidikan

Karakter. Retrieved from: https://w ww.kemendagri.go.id/arsip/detail/10

365/perpres-no-87-tahun-2017

Silkyanti, F. (2019). Analisis Peran Budaya Sekolah yang Religius dalam Pembentukan Karakter Siswa. Indonesian Values and Character Education Journal, Vol 2 No 1, Tahun 2019, p-ISSN: 2615-4684 e-ISSN: 2615-6938. Retrieved from: https://ejournal.undiksha.ac.id/index. php/IVCEJ/article/view/17941

Supraptiningrum and Agustini. (2015). Membangun Karakter Siswa Melalui Budaya Sekolah Di Sekolah Dasar. Jurnal Pendidikan Karakter. Tahun V, Nomor 2, Oktober 2015, DOI: https://doi.org/10.21831/jpk.v0i2.862 5. Retrieved from: https://journal.u ny.ac.id/index.php/jpka/article/view/ $\underline{8625}$

Trianto. (2014). Model Pembelajaran Terpadu (Konsep, Strategi, dan Implementasinya dalam Kurikulum Tingkat Satuan Pendidikan). Jakarta: PT Bumi Aksara 